\title{
Museus em periferias urbanas brasileiras
}

\section{Museums in Brazilian urban periphery}

Camila de Fátima Simão de Moura Alcântara*

*Universidade Federal do Pará - Belém, PA, Brasil

Doutoranda em Antropologia (bolsista Capes)

camilafsmoura@gmail.com

https://orcid.org/0000-0001-9258-977X 


\title{
Resumo
}

Atualmente, no Brasil, iniciativas comunitárias nos centros urbanos expressam seus valores sociais e culturais por meio de processos museológicos. Neste artigo, o objetivo é investigar os museus e as cidades como campos etnográficos da antropologia, ao identificar esses processos em bairros periféricos dos centros urbanos brasileiros. O estudo se aplica à ação-piloto do Programa Pontos de Memória do Instituto Brasileiro de Museus, diante da experiência etnográfica com o Ponto de Memória da Terra Firme, iniciativa comunitária que desenvolve processo museológico no bairro da Terra Firme em Belém, Pará. A partir da análise das estratégias e relações estabelecidas para a consolidação dos Pontos de Memória conclui-se que esses processos museológicos se dão a partir de uma vontade política de registro da memória social por meio da apropriação de patrimônios reconhecidos pelos seus moradores, consolidando-se, assim, em museus comunitários.

Palavras-chave: museus; periferias; memória social; bairro da Terra Firme.

\begin{abstract}
Nowadays, in Brazil, community initiatives in urban centers express their social and cultural values through museological processes. The main objective in this article is to investigate museums and cities as anthropological ethnographic fields, when identifying these processes in low income neighborhoods of Brazilian urban centers. The study is applied to the Pilot-project for the Memory Points Program, linked to the Brazilian Institute of Museums, based on the ethnographic experience with the Ponto de Memória da Terra Firme, a community initiative that develops a museological process in the neighborhood of Terra Firme in Belém, Pará. After analyzing strategies and relations established due to the consolidation of the Memory Points, it is concluded that these museological processes derive from a political will to register social memory through the appropriation of cultural heritages recognized by its residents, thus consolidating in community museums.
\end{abstract}

Keywords: urban peripheries; social memory; neighborhood of Terra Firme. 


\section{Apresentação dos campos de análise ${ }^{1}$}

O debate sobre o papel das instituições museológicas como espaços de representação cultural e política dos variados grupos e categorias sociais existentes em seus acervos e o modo como a antropologia pode contribuir na defesa da diversidade cultural dentro desses espaços tem persistido ao longo dos últimos anos. Contudo, o impasse entre o que, quem e como representar mantém-se até hoje dentro dos conhecidos museus etnográficos e as novas modalidades de museus na perspectiva antropológica, como os museus indígenas, os museus sociais e os ecomuseus.

Essa preocupação recai, segundo Abreu (2007), ao interesse desses dois campos de pesquisa, a antropologia e os museus, pelo patrimônio cultural das sociedades existentes. Busca-se com essa relação investigar o processo de bens culturais dado por uma política institucional que define a representação da memória e da identidade coletiva do grupo estudado. Portanto, para a autora (Abreu, 2007), esses dois campos favorecem a interação, a interseção e o englobamento do patrimônio enquanto prática de colecionamento (material) e de registro da memória social (imaterial).

Nas sociedades urbanas os patrimônios culturais se constituem nas diferentes formas de sociabilidades que acontecem nas cidades. Dentro das cidades modernas ocorrem vínculos entre os sujeitos urbanos de diferentes combinações, devido à diversidade cultural e a heterogeneidade social (Magnani, 2013), estabelecidas pelas trocas materiais e simbólicas que são construídas no seu cotidiano. Por meio da antropologia urbana conseguimos "ir às cidades (ou, simplesmente, permanecer nelas)" (Hannerz, 2015, p. 11) para a compreensão de uma série de fenômenos sociais e culturais que possam ser examinados a partir da diversidade humana (Hannerz, 2015). Contemplando, assim, os museus e as relações que se estabelecem com os patrimônios das cidades.

Os museus como fenômenos sociais são reflexos dos contextos histórico-cultural e político nos quais foram criados, mantidos, dinamizados e (res)significados, afirma Abreu (2012). Para tal, existe uma diversidade de museus quanto à forma e a maneira de ser que são incorporados a partir da

1 O presente trabalho foi realizado com apoio da Coordenação de Aperfeiçoamento de Pessoal de Nível Superior - Brasil (Capes) - Código de Financiamento 001. 
capacidade humana de transformação sociocultural (Abreu, 2012). Neste texto, tratarei de uma forma específica que emerge de movimentos sociais pela transformação social do território, os chamados museus comunitários ou sociais.

Com o interesse de contribuir para o estudo desse fenômeno que vem crescendo no Brasil desde o fim do século XX, nos últimos anos, busco indicar as possibilidades e processos que implicam a relação entre museus e bairros localizados em periferias urbanas a partir da análise do Programa Pontos de Memória (PPM) do Instituto Brasileiro de Museus (Ibram). Neste momento, apresentarei as estratégias e relações estabelecidas em processos museológicos que ocorrem nas periferias urbanas brasileiras, tomando como estudo de caso os contemplados pela ação-piloto do Programa Pontos de Memória. Em destaque, a minha experiência etnográfica no bairro da Terra Firme, Belém, Pará, diante ao processo museológico realizado pelo Ponto de Memória da Terra Firme (PMTF).

O Ibram, a partir da consolidação de políticas públicas voltadas para os campos do patrimônio cultural, da memória social e dos museus (Moura, 2016), implementou no ano de 2009 o PPM, em parceria com os programas culturais Mais Cultura e Cultura Viva, do Ministério da Cultura (MinC), e o Programa Nacional de Segurança com Cidadania (Pronasci), do Ministério da Justiça. O PPM, com o apoio da Organização dos Estados Ibero-Americanos (OEI/Brasil), identificou 12 comunidades localizadas em bairros periféricos pelo Brasil, que desenvolviam um trabalho sistemático de identificação, registro, compartilhamento e preservação de suas memórias, para realizar um experimento prático do programa, o que viria a ser a ação-piloto do PPM (Organização dos Estados Ibero-Americanos, 2016).

Integraram a essa ação-piloto as seguintes comunidades: Brasilândia (São Paulo), Beiru (Salvador), Coque (Recife), Estrutural (Brasília), Grande Bom Jardim (Fortaleza), Jacintinho (Maceió), Lomba do Pinheiro (Porto Alegre), Pavão-Pavãozinho - Cantagalo (Rio de Janeiro), São Pedro (Vitória), Sítio Cerrado (Curitiba), Taquaril (Belo Horizonte) e Terra Firme (Belém). A inserção dessas comunidades no Programa Pontos de Memória consolidou-se na formação de iniciativas comunitárias em memória social e museologia comunitária que desenvolvem processos museológicos nesses territórios.

Na Figura 1, a seguir, é possível identificar onde estão localizados essas iniciativas comunitárias, e como cada uma denomina o seu processo 
museológico. Com destaque para o bairro da Terra Firme onde se localiza o Ponto de Memória da Terra Firme (ponto 1), lugar de imersão etnográfica para essa pesquisa.

\section{Legenda}

1. Ponto de Memória da Terra Firme (Belém-PA)

2. Ponto de Memória Grande Bom Jardim (Fortaleza-CE)

3. Museu Mangue do Coque (Recife-PE)

4. Museu de Cultura Periférica (Maceiró-AL)

5. Ponto de Memória do Beiru (Salvador-BA)

6. Ponto de Memória da Estrutural (Brasília-DF)

7. Museu do Tuaquaril (Belo Horizonte - MG)

8. Ponto de Memória Grande São Pedro (Vitória-ES)

9. Museu da Favela (Rio de Janeiro-RJ)

10. Ponto de Memória da Brasilândia (São Paulo-SP)

11. Museu da Periferia - Curitiba-PR)

12. Ponto de Memória Lomba de Pinheiro (Porto Alegre-RS)
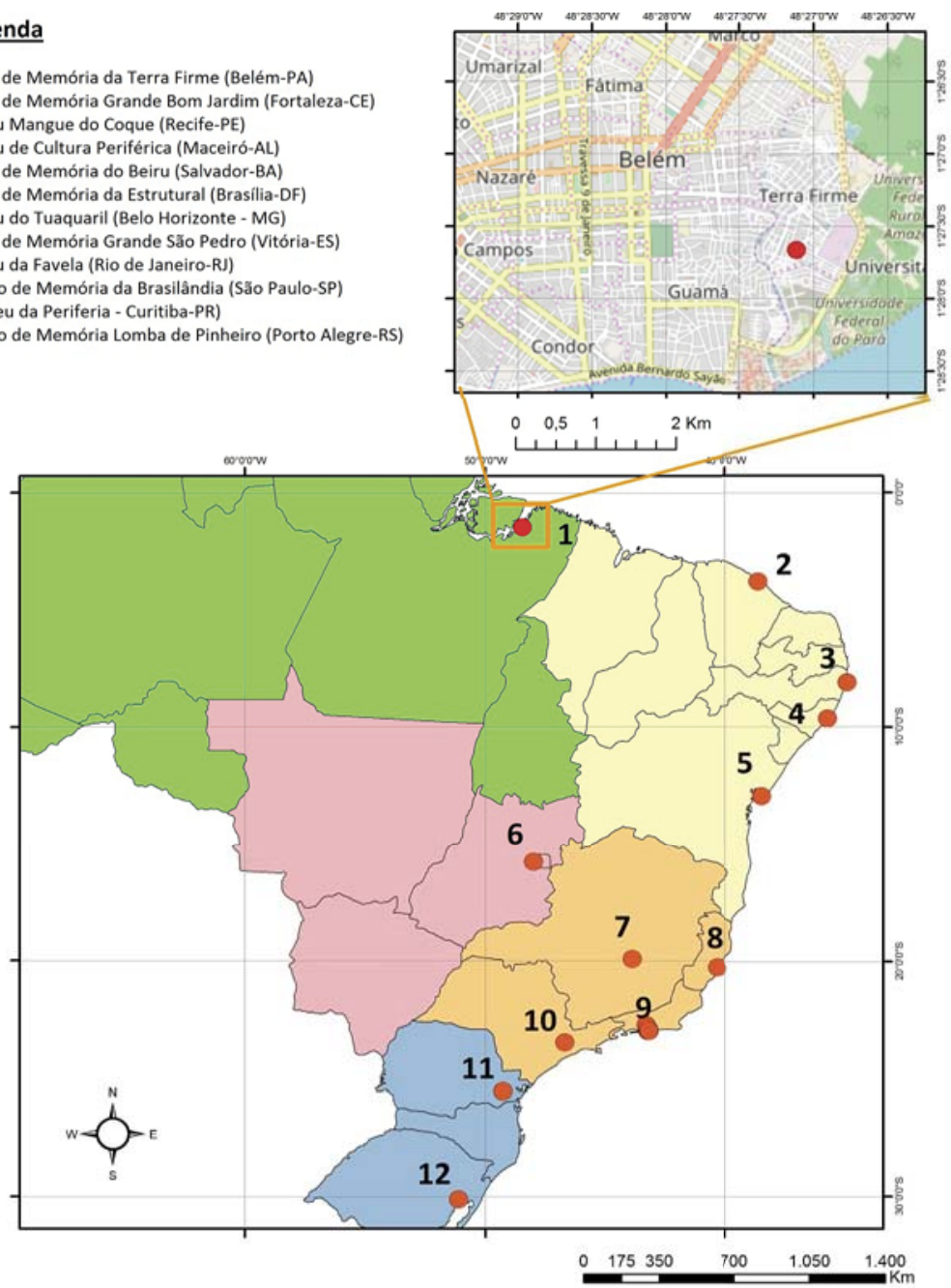

Figura 1. Mapa de localização dos pontos pioneiros do Programa Pontos de Memória (imagem: Tallyta Suenny, 2018). 
Observa-se, portanto, que a instituição "museu" ganhou novos significados e formulações distintas dos padrões conhecidos durantes o século XIX e a primeira metade do século $\mathrm{XX}$, onde imperavam os museus etnográficos de grandes coleções de "objetos exóticos" dos povos aldeados. Os processos museológicos desenvolvidos por essas iniciativas comunitárias estão vinculados aos compromissos sociais e éticos que os museus assumem com os grupos sociais representados dentro dessas instituições (Chagas; Gouveia, 2014). Os pontos pioneiros, ${ }^{2}$ como as iniciativas comunitárias contempladas pela ação-piloto do PPM se autodeclaram, trabalham em seus territórios pela democratização de instituições, como os museus, e dos patrimônios culturais ao valorizarem e difundirem seus saberes e práticas socioculturais dentro de processos museológicos, voltados para a educação, a pesquisa e a mobilização social.

Frente a esse campo de estudo, trago minha experiência etnográfica com o Ponto de Memória da Terra Firme para discutir como processos museológicos urbanos que partem de iniciativas comunitárias contribuem para a valorização da memória social produzida dentro de periferias urbanas. Faço reflexões sobre os processos desempenhados pelos pontos pioneiros dentro dos movimentos políticos sociais que surgem a partir da "consciência cultural" (Sahlins, 1997) dessas iniciativas comunitárias. Dessa maneira, proponho também com este artigo contribuir para o debate sobre a antropologia e os museus ao abordar os museus comunitários dentro dos centros urbanos brasileiros.

\section{A formação dos Pontos de Memória}

O interesse em ser protagonista de sua própria história tornou-se um ato político de muitos grupos pelo Brasil, e os museus comunitários são reflexos desse interesse, como resultado de movimentos instaurados no século passado, pertinentes até o momento, como o indígena, o negro, o LGBT, o feminista, e o de interesse neste artigo, o oriundo de comunidades periféricas. Para Abreu (2008),

2 No ano de 2011 tornou-se público o primeiro edital do Prêmio Pontos de Memória, provocando o surgimento de novas iniciativas comunitárias, reconhecidas e premiados pelo Ibram. Atualmente, são reconhecidas 362 iniciativas no Brasil e 12 no exterior. 
esses grupos sociais se apropriam do patrimônio como instrumento para suas conquistas.

O patrimônio, neste texto, é pensado a partir das reflexões de José Reginaldo Gonçalves (2005, p. 17): como termo etnográfico é "uma categoria extremamente importante para a vida social e mental de qualquer coletividade humana". Como bens patrimoniais, transitam entre o material e o imaterial por meio de relações sociais e simbólicas que provocam ressonâncias ${ }^{3} \mathrm{em}$ seus representantes e espectadores (Gonçalves, 2005). Nos museus representam o que deve ser lembrado e esquecido, configurando uma forma de pensar sobre as realidades existentes de cada grupo.

Os museus emanados de iniciativas comunitárias tornam-se estratégias de organização da memória e afirmação da identidade coletiva de seus grupos. "O museu comunitário é um processo, mais que um produto [...] uma ferramenta para avançar na autodeterminação, fortalecendo as comunidades como sujeitos coletivos que criam, recriam e decidem sobre sua realidade" (Morales Lersch; Camarena Ocampo, 2004, p. 4). Por meio dos museus, as comunidades buscam exercer poder "sobre o que é seu", ao lutarem contra a expropriação, praticando o direito de falarem de si mesmas por si mesmas.

O Programa Pontos de Memória é resultado de um movimento político no campo museológico brasileiro que iniciou com a construção coletiva da Política Nacional de Museus (2003). As transformações no campo foram favoráveis à formulação e aplicação de políticas públicas culturais afirmativas, com ampla participação popular de agentes comunitários envolvidos com seus patrimônios.

O Museu da Maré, na comunidade da Maré, cidade do Rio de Janeiro, nesse período que representou a aplicação de estratégias sociais e simbólicas para o campo do museu, se consolidava em uma experiência exitosa de museologia comunitária no país. O museu chamou a atenção de diversos segmentos da sociedade por ser na periferia, feito por gente da periferia, e abrangeria temas locais e universais. "O museu era fundamentalmente criado para fomentar a autoestima de trabalhadores que habitavam o lado considerado feio e violento

3 Ressonância é pensada a partir de Greenblatt (1991 apud Gonçalves, 2005), que diz que o objeto exposto atinge um universo mais amplo ao evocar no espectador as forças culturais complexas e dinâmicas das quais ele emergiu e das quais ele é, para o espectador, o representante. 
da cidade" (Abreu, 2007, p. 173). Nele identifica-se a manifestação de memória, patrimônio e museu pelos seus moradores (Chagas; Abreu, 2007).

O processo museológico instaurado na Maré é só um exemplo de processos protagonizados por povos, comunidades e movimentos sociais que militam para serem reconhecidos e valorizados como parte integrante e indispensável da memória social brasileira (Organização dos Estados Ibero-Americanos, 2016). Contudo, o interesse nessa pesquisa pelo Museu da Maré deve-se ao papel significativo que desempenha para a memória e a história de comunidades periféricas no Brasil, representando a periferia como "lugar de cultura, de memória, de poética, de trabalho, e não apenas como território privilegiado da bala perdida ou teatro de guerra, onde policiais enfrentam bandidos e bandidos enfrentam policias", como afirmam Chagas e Abreu (2007, p. 133).

Territórios como o da Maré são pertinentes em todo o Brasil, onde, devido aos agravantes da desigualdade social no país, os sujeitos que os compõem enfrentam as duras condições de vida por meio de redes de sociabilidade que compartilham gostos e valores socioculturais. Quando esses territórios ganham os holofotes da mídia e o apoio do governo, como acontece na Maré, tais sujeitos fortalecem sua autoestima e afirmam suas origens e códigos, ao participarem de práticas culturais próprias inserindo-se na cena urbana (Silva, 2013). Dessa maneira, a experiência do Museu da Maré serviu como modelo para a consolidação dos Pontos de Memória.

A criação do Programa Pontos de Memória se deu a partir do estreitamento entre o MinC e o Ministério da Justiça, onde se discutia antes mesmo da criação do Ibram, a elaboração de programas culturais em comunidades de periferias urbanas, devido os agravantes sociais que se instauram nesses lugares. $O$ antropólogo José Nascimento Junior, presidente do Ibram no período de 2009 a 2013, em entrevista a mim concebida, afirmou que "o interesse maior dessa parceria, MinC e Ministério da Justiça, era minimizar a violência em regiões de favela pelo Brasil".

Os Pontos de Cultura eram uma realidade no país, não criando ou recriando estruturas culturais (como centro de cultura), mas sim potencializando entidades ou grupos já existentes que se utilizam do desenvolvimento da cultura para a transformação social de comunidades e territórios. No diálogo entre os dois

4 Entrevista realizada em 01/05/2017; as demais citações de Nascimento se referem a essa mesma entrevista. 
ministérios outros desdobramentos tornavam-se possível em defesa da cultura como um processo autônomo e de protagonismo comunitário. Conforme Nascimento pondera: "Criou-se uma rede de relações internas de solidariedade a partir da memória, em que se pensava estimular e valorizar o que já existia em torno de uma dinâmica de memória."

Observo que essa dinâmica de memória, mencionada pelo entrevistado, acontece a partir da vontade política de registro da memória social de grupos historicamente negligenciados, com o desenvolvimento de ações específicas, por exemplo: a realização de entrevistas com os mais velhos, o registro de fotografias das realidades existentes em seus territórios, a coleta de materiais significativos para o grupo, entre outros. Assim como ocorreu com o Museu da Maré e outras iniciativas de Pontos de Cultura.

Portanto, a conversa com Nascimento esclarece que a proposta de criação dos Pontos de Memória pelo Ibram era uma realidade em diversos contextos da sociedade brasileira, por meio de registro da memória em etnias indígenas, comunidades rurais, comunidades quilombolas, bem como em grupos sociais urbanos. A novidade com a implantação do PPM é a formulação de políticas públicas afirmativas de memória e patrimônio voltadas, inicialmente, para comunidades periféricas.

Segundo Fredrik Barth (1969, p. 34 apud Sahlins, 1997, p. 131), em relação às formas contemporâneas de organização "os movimentos políticos constituem novos modos de fazer com que as diferenças culturais sejam organizacionalmente relevantes". Desse modo, movimentos políticos em torno da cultura oriunda da periferia põem em questão a possibilidade de se colocar de forma diferente nas estruturas que compõem a cidade. O objetivo inicial da ação-piloto dos Pontos de Memória era o de apoiar ações e iniciativas de reconhecimento e valorização da memória social a partir do protagonismo comunitário, desenvolvendo metodologias específicas voltadas para museu, memória e cidadania. Sob o entendimento de que os museus seriam meios de mudança social e desenvolvimento sustentável de comunidades que não tinham a oportunidade de expor seus valores sociais e culturais (Moura, 2016), trazendo, assim, novas reflexões sobre a relação entre os museus e os grandes centros urbanos brasileiros.

A aplicação da ação-piloto teve como característica o trabalho coletivo entre os agentes comunitários e técnicos do Ibram, especificamente os lotados no Departamento de Processos Museais (DPMUS) da autarquia federal. Segundo 
Avelar (2015), o trabalho coletivo possibilitou o diagnóstico de potencialidades, a capacitação de agentes de memória, a realização de inventários participativos e a elaboração de planos de ação. Essas ações viabilizaram a concretização de produtos de difusão, como exposições, projetos editoriais, audiovisuais, performances variadas, aos quais asseguraram a instalação e manutenção dos Pontos de Memória.

No período de 2009 a 2013, atuei como conselheira e consultora do Ponto de Memória da Terra Firme, em Belém. Essa experiência me possibilitou desenvolver uma dissertação de mestrado (Moura, 2016) e estar elaborando minha tese de doutorado diante dos desdobramentos do Programa Pontos de Memória, ambas inseridas no Programa de Pós-Graduação em Antropologia, na Universidade Federal do Pará. Atualmente, sou colaboradora no PMTF.

Observo a partir dessa relação estreita com Pontos de Memória que as iniciativas comunitárias em memória social e museologia comunitária criam espaços para abrigar o presente e com ele o futuro de uma comunidade autêntica, consciente e gestora de seus valores (Moura, 2016). Esses espaços podem ser físicos, como salas, casas ou prédios; e também subjetivos, como por exemplo a determinação do território em que se atua, se reside e se constroem identidades. Contudo, o interesse aqui não é como esse espaço se estabelece, mas sim as relações que se estabelecem nesses espaços para o registro da memória e identificação do patrimônio cultural.

As dinâmicas de memória (como se referiu José Nascimento) dos pontos pioneiros podem ser percebidas como a forma com que esses grupos criam práticas e soluções criativas para reagir ao sistema imposto das elites econômicas e políticas no país, resolvendo seus problemas e organizando suas vidas (García Canclini, 1988). Dessa forma, expressam seu poder de resistência e criatividade por meio de processos museológicos de mobilização, identificação, ação e cidadania; assim, a comunidade se faz sujeita no ato de formular, executar e manter o processo (Moura, 2016). Alguns se (auto)reconhecem como museus (de caráter comunitário), outros como apenas Pontos de Memória (ver Figura 1), mas a maioria se utiliza das possibilidades criadas a partir do processo museológico para se (auto)conhecer culturalmente, com o interesse de servir e atender as necessidades de seu grupo de pertença.

Portanto, dentro das cidades esses Pontos de Memória possibilitam novas formas de representação, definição e reinvenção do fenômeno museu. Isso 
se deve ao processo museológico de seus territórios, que são apreendidos por diversos atores e segmentos que compõem as cidades. Frente aos (re)arranjos sociais que esses processos possibilitam em seus territórios, sigo as discussões em torno de como se organizam para que o programa se institucionalize como política pública de registro das memórias historicamente negligenciadas dos processos de valorização da memória social, trabalhando junto na luta pelo direito á memória.

\section{Anseio por política pública}

Periferias são territórios localizados em centros urbanos que se mantêm à margem de políticas públicas e que indicam uma distância simbólica constituída pela perda de qualquer coisa que coloca em ordem o urbano, e de um estilo de vida marcado por padrões de conforto e acesso a recursos materiais (Wacquant, 2007). Como fenômenos socioculturais e políticos emergem de movimentos sociais por moradia e equipamentos urbanos coletivos dentro das grandes metrópoles. Processos museológicos nesses territórios permitem o desenvolvimento de certas redes e a criação de grupos sociais políticos, que observados de formas distintas propiciam a consolidação de territórios como representação da diversidade cultural das cidades.

Os pontos pioneiros desempenham um papel significativo para a compreensão de seus territórios como espaços de trocas sociais e simbólicas, que a todo momento negociam o seu modo de ser e estar nas cidades. Segundo Abreu (2012), é preciso refletir sobre o papel da cidade no advento da modernidade, em que a partir da existência das metrópoles o lugar da vida moderna torna-se fluído e híbrido. "A cidade moderna vem também expressando cada vez mais a instabilidade dos sentidos num mundo onde as transformações foram seguindo um curso veloz, demolindo as referências e seus múltiplos significantes", afirma a autora (Abreu, 2012, p. 58). Desse modo, os museus tendem a acompanhar esse processo ao se adequar às reviravoltas políticas, sociais e econômicas das sociedades.

Os museus comunitários são exemplos dessa mudança, ao se adequarem a uma nova forma política, acadêmica e institucional de representação do outro. Os grupos que desenvolvem esses espaços passaram a se impor como 
sujeitos ativos em relações interculturais dentro de instituições museológicas (Abreu; Lima Filho, 2007). Deixaram de ser objeto de estudo, exibido nos grandes museus, para negociar a construção de processos museológicos em seus territórios de pertença.

Essa negociação acontece entre a escolha do que lembrar e do que esquecer, utilizando-se da memória para afirmação de uma identidade coletiva, ao reconhecer a cultura em diversas possibilidades no espaço ocupado pelos indivíduos. No caso dos territórios periféricos em que acontecem os pontos pioneiros o abandono político é também marcado pela falta de representatividade em "museus de cidades". Segundo Meneses (1985), esses museus mantêm-se estáveis e imunes às mudanças da urbanização, preocupando-se com o processo histórico e político de classes hegemônicas.

Contudo, as transformações no campo museológico brasileiro que levaram à criação do Programa Pontos de Memória favoreceram o reconhecimento de iniciativas comunitárias em memória social e museologia comunitária pelo país. Destacam-se com essas iniciativas a possibilidade de produção de narrativas singulares e de movimentos políticos de valorização dos patrimônios culturais, apreendido por seus detentores. Levou-se em consideração para a escolha das 12 iniciativas comunitárias, identificadas na Figura 1: a história dos grupos; a realização de ações voltadas para a afirmação da memória social; a apropriação da cultura popular; e a vontade de formarem coletivamente um museu comunitário.

Desse modo, no período de 2009 a 2013, a ação-piloto do Programa Pontos de Memória se constituiu em: Teias da Memória ${ }^{5}$ - encontros nacionais com as comunidades selecionadas no programa, com o objetivo de estimular a troca de experiências, a gestão participativa no PPM e reflexões sobre as realidades socioculturais dos lugares onde atuam os pontos de memória; capacitação técnica - a coordenação do programa dividiu-se entre os pontos pioneiros ministrando oficinas de formação para os conselhos gestores ${ }^{6}$ das iniciativas, com temas relacionados à memória, patrimônio, identidade e museus; consultoria locais

5 A Teia da Memória teve quatro edições: em 2009, na cidade de Salvador; em 2010, na cidade de Fortaleza; ainda em 2010, na cidade do Rio de Janeiro; e a última, em Belém, no ano de 2014.

6 Representatividades civis dos pontos pioneiros. 
- seleção de consultores locais para atuarem nas comunidades afim de viabilizar consultoria técnica-operacional em torno da memória social legitimada por esses grupos; redes de pontos de memórias - com o interesse de aproximar e articular ações e trocas de experiências entre iniciativas culturais (Chagas; Gouveia, 2014; Moura, 2016; Organização dos Estados Ibero-Americanos, 2016).

As ações foram realizadas de maneira gradativa de acordo com as peculiaridades locais, estruturais e de momento, tornando-se essenciais para a consolidação do Programa Pontos de Memória como uma política cultural (Organização dos Estados Ibero-Americanos, 2016). O processo ao longo dos anos fortaleceu as iniciativas comunitárias como grupos políticos organizados importantes por contribuem para transformações socioculturais e educacionais em seus territórios. $\mathrm{O}$ fortalecimento desses grupos deve-se muito ao movimento político, constituído em sua maioria por agentes comunitários presentes nos pontos pioneiros, que tomaram posicionamentos críticos frente às mudanças que começaram a surgir dentro do PPM (Moura, 2016).

Ao longo dos últimos anos mudanças significativas no cenário político brasileiro interferiram diretamente no andamento do Programa Pontos de Memória. O campo museológico precisou se articular de forma diferente para garantir que as medidas tomadas desde 2003 com a implantação da Política Nacional de Museus pudessem ser mantidas. As estratégias sociais e simbólicas para 0 campo dos museus, que era prioridade quando se criou o PPM, tomou outros direcionamentos a partir do ano de 2012.

Tornaram-se cada vez mais escassas as atividades que corresponderam à metodologia participativa da ação-piloto do Programa Pontos de Memória. A troca de experiências entre as iniciativas comunitárias, o diálogo entre o Ibram e as comunidades e a formação de organismos independentes, como as redes de Pontos de Memória, e o experimento prático que levaria a implementação de uma política pública de memória social e museologia comunitária pareciam ter fim.

Entretanto, os pontos pioneiros se fortaleceram enquanto grupos organizados, mobilizando as demais iniciativas comunitárias contempladas pelo Programa Pontos de Memória. Desde o ano de 2011, mais de 300 iniciativas comunitárias passaram a ser reconhecidas como Pontos de Memória pelo Ibram por meio de editais de premiação. O crescimento de Pontos de Memória 
no país resultou no aparecimento de redes temáticas ${ }^{7}$ e territoriais ${ }^{8}$ provocadas pelo interesse de atuarem no segmento ou em temas específicos.

Assim, foi criada no ano de 2012 a Comissão Provisória de Gestão Compartilhada/Participativa (Cogepaco) do Programa Pontos de Memória, com representação de integrantes dos pontos pioneiros e pontos premiados. ${ }^{9}$ A Cogepaco desempenhou ações de fortalecimento do PPM com a intenção de contribuir para a formação da política pública de Pontos de Memória propiciando a criação de um Conselho de Gestão Compartilhada e Participativa. Dentre as ações, destaca-se a Carta dos Pontos de Memória e inciativas comunitárias em memória e museologia social de 2012, redigida com a colaboração de grupos organizados em defesa da memória social brasileira (Instituto Brasileiro de Museus, 2012).

Ao longo do século XX, segundo Moraes (2009), políticas públicas foram moldadas e, por vezes, definidas por condições locais e internacionais, influenciadas por crenças, ideologias e percepções socioeconômicas, viabilizadas por alianças conjunturais na elaboração e avaliação de grupos da sociedade civil por demandas prioritárias. Para o campo museológico, as políticas públicas foram resultados de um movimento político de sujeitos e grupos sociais que desejavam implantar um sistema de gestão por programas específicos que atendesse às demandas da sociedade no segmento cultural. Para o autor, estudar o museu no contexto das políticas públicas requer consideração dos sentidos e dos limites da democracia, da universalização do direito e do acesso à informação na sociedade brasileira, "o que permite saber quem tem o poder de definir e orientar ações e garantir sua continuidade, a capacidade de pautar e se fazer permanente e como o faz" (Moraes, 2011, p. 83).

A Política Nacional de Museus representou uma mudança de postura do Ministério da Cultura, por abranger todos os museus brasileiros, independentemente da sua vinculação institucional, ou se público ou privado. Propõe-se com

7 Por exemplo, a Rede de Memórias e Museus de Terreiros da Bahia e a Rede LGBT de Memória e Museologia Social.

8 Em destaque para a Rede de Memória e Iniciativas Comunitárias da Região Norte, onde participa o Ponto de Memória da Terra Firme.

9 Termo utilizado pelas iniciativas comunitárias que integraram a ação-piloto do PPM ao se referirem às iniciativas de Pontos de Memória contempladas por editais de premiação, a partir de 2011. 
essa política a articulação da sociedade civil com entes da federação, estaduais e municipais. A Cogepaco tomou como referência os desdobramentos da Política Nacional de Museus para exigir que o Ibram desempenhasse suas medidas frente às iniciativas de memória social e museologia comunitária conjuntamente com os grupos organizados dos Pontos de Memória.

Isso é observado na Carta dos Pontos de Memória e inciativas comunitárias em memória e museologia social, em que Cogepago, Ibram e outros participantes da construção desse documento se comprometeram a levar em consideração a memória social de comunidades, grupos e sujeitos que historicamente foram negligenciados da constituição da memória brasileira. Firmaram o compromisso de reconhecer, respeitar e valorizar a diversidade sociocultural desses grupos por meio de trabalhos participativos e em rede dentro do seio de suas próprias comunidades e entes da federação (Instituto Brasileiro de Museus, 2012).

A Carta dos Pontos de Memória serviu como orientação para que o PPM se institucionalizasse como política pública do Ibram, de interesse das iniciativas comunitárias e dos técnicos envolvidos na aplicação do programa. A mobilização da Cogepaco conseguiu com que representantes de todos os pontos pioneiros, pontos premiados (editais 2011 e 2012) de cada rede (regional ou temática) de memória e museologia social mapeada pelo Ibram estivessem no $6^{\circ}$ Fórum Nacional de Museus, em Belém, no ano de 2014, para participar da IV Teia da Memória (Instituto Brasileiro de Museus, 2017b). No total participaram do evento 120 iniciativas comunitárias (107 no Brasil e 13 no exterior), além de servidores e consultores do Ibram e demais interessados que tiveram livre acesso a partir da inscrição no $6^{\circ}$ Fórum.

Os três dias de debates calorosos, de 23 a 25 de novembro de 2014, dos participantes da IV Teia da Memória estão descritos na minha dissertação de mestrado, por meio de uma análise situacional (Gluckman, 2010; Van Velsen, 2010), onde observei o andamento do Programa Pontos de Memória, os posicionamentos das iniciativas comunitárias perante as medidas tomadas pelo Ibram e a forma como o Ponto de Memória da Terra Firme se inseria nas discussões e mobilizações dos pontos pioneiros (Moura, 2016). Contudo, é interessante retornar às análises feitas durante a IV Teia para indicar que o principal encaminhamento do evento foi o debate e aprovação da minuta (consultar Instituto Brasileiro de Museus, 2017b) de portaria que institui o Conselho de 
Gestão Compartilhada e Participativa do Programa Pontos de Memória, com propostas que surgiram ao longo de dez encontros regionais. ${ }^{10}$

Com funções consultiva, deliberativa, propositiva e mobilizadora o Conselho de Gestão Compartilhada e Participativa foi eleito em plenária como instância colegiada permanente de debate e articulação para construção e fortalecimento de políticas públicas de museologia social. Com dez representantes do governo ${ }^{11} \mathrm{e}$ dez representantes da sociedade civil, entre as atribuições do conselho, conforme $\mathrm{o}$ artigo $5^{\circ}$ da portaria, destaco abaixo as que fundamentam como o direito à memória de grupos como os Pontos de Memória está garantido na formulação de políticas públicas afirmativas no campo dos museus:

VIII - Atuar em prol da garantia do direito à memória, prioritariamente das comunidades, grupos e sujeitos historicamente excluídos.

$\mathrm{X}$ - Incentivar a participação democrática dos Pontos de Memória, das iniciativas comunitárias de memória e museologia social e suas redes na gestão de políticas e dos investimentos públicos na área da memória e museologia social. XII - Garantir a implementação de instrumentos de gestão participativa e compartilhada para que os Pontos de Memória e demais iniciativas comunitárias de memória e museologia social sejam geridas por instâncias participativas, organizadas para esta finalidade, no seio de suas próprias populações.

XV - Propor instrumentos e iniciativas que garantam a circulação e distribuição da produção dos Pontos de Memória e demais iniciativas comunitárias em memória e museologia social, com apoio do Ibram e parceiros.

A seguir, na Figura 2, temos o registro dos representantes da sociedade civil (titulares e suplentes) que compuseram o Conselho de Gestão Compartilhada e Participativa do Programa Pontos de Memória. Na imagem estão cinco representantes dos Pontos de Memória, sendo um por cada região; um representante

10 Realizados no período de outubro a novembro de 2014, pela equipe do Programa Pontos de Memória, nos estados do Ceará, São Paulo, Minas Gerais, Maranhão, Alagoas, Rio Grande do Sul e Distrito Federal. Com participação de membros da Cogepaco, Pontos de Memória e Redes Temáticas e Territoriais de Memória e Museologia Social (Instituto Brasileiro de Museus, 2017b).

11 Representantes do Instituto Brasileiro de Museus, do Instituto do Patrimônio Histórico e Artístico Nacional, Secretaria da Cidadania e Diversidade Cultural/MinC, Ministério da Educação, Secretaria de Direitos Humanos da Presidência da República, Secretaria Especial de Promoção da Igualdade Racial e Fundação Nacional do Índio. 
eleito pelos 12 Pontos de Memória pioneiros; dois representantes de redes regionais; ${ }^{12}$ e dois representantes de redes temáticas.

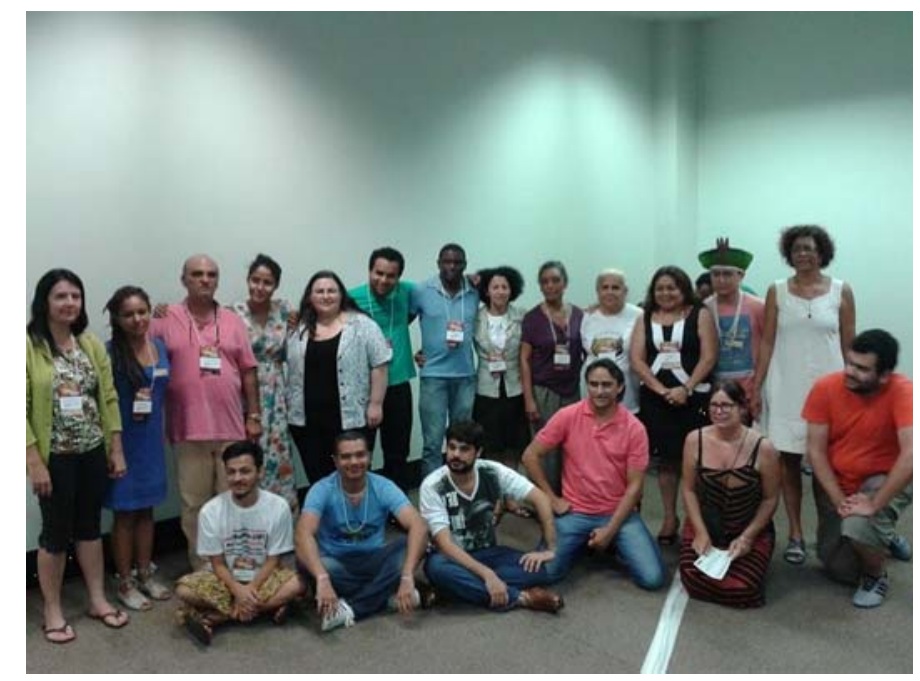

Figura 2. Representantes civis do Conselho de Gestão Compartilhada e Participativa do Programa Pontos de Memória (foto da autora, 2014)

Durante a IV Teia da Memória, percebiam-se as articulações internas das iniciativas comunitárias de debaterem e aprovarem a minuta do conselho com mais fidelidade às discussões feitas nos encontros regionais com a Cogepaco. A maior interferência dos funcionários e consultores do Ibram partiu do questionamento da procuradora $\mathrm{a}^{13}$ do instituto sobre a viabilidade desse conselho, por apresentar em suas funções o caráter deliberativo, de administração quanto ao direcionamento da política pública de Pontos de Memória. A procuradora defendia que quando fosse encaminhar o texto final de formação do conselho pelas instâncias da autarquia federal ele poderia ser recusado por esse motivo, haja vista que não

12 Na plenária da IV Teia da Memória foram eleitas Helena do Socorro Alves Quadros e Francisca Rosa Silva dos Santos, integrantes do Ponto de Memória da Terra Firme, como representantes das redes regionais.

13 Naquele momento, Eliana Sartori. 
caberia participação de membros externos nas decisões administrativas e financeiras de instituições museológicas, tampouco no Ibram.

A proposta da procuradora era a aprovação de um comitê de caráter consultivo e mobilizador dentro das políticas públicas de memória e museologia social do Ibram. No entanto, as iniciativas recusaram a proposta e aprovaram em plenária, na cidade de Belém, o texto final do Conselho de Gestão Compartilhada e Participativa do Programa Pontos de Memória tal como foi proposto. Apesar da euforia com a eleição do conselho, este só se institucionalizaria com a aprovação da portaria no Ibram, algo que se prolongou por três anos.

Mais uma vez o cenário político no Brasil mudou e houve desmobilização de políticas públicas de cultura e educação, tendo como agravante o impeachment da presidenta Dilma Rousseff, no ano de 2016. Assumiu no país um governo sem diálogo, propício a privatização das instituições e desmontes dos serviços públicos, com descaso e abandono do patrimônio cultural brasileiro. Isso favoreceu que o Ibram tomasse outro direcionamento, não mais priorizando a gestão compartilhada e participativa de suas políticas.

Dessa maneira, as iniciativas comunitárias perderam força dentro do instituto e não conseguiram, no período de 2015 e 2016, avançar nas discussões sobre a institucionalização do Programa Pontos de Memória. A portaria do Conselho de Gestão Compartilhada e Participativa do Programa Pontos de Memória foi engavetada e os representantes eleitos se desmobilizaram. Somente em 2017 esse grupo volta a se reunir durante o $7^{\circ}$ Fórum Nacional de Museus, na cidade de Porto Alegre.

Alguns membros eleitos do conselho mobilizaram-se para garantir a participação de iniciativas comunitárias no evento de promoção do Ibram, como já era recorrente nas três últimas edições. Assim, os Pontos de Memória participaram da programação oficial do evento com apresentações em painéis, participações em reuniões específicas e discussões em grupos de trabalho. E, com o apoio de colaboradores do PPM, em suas localidades e em nível nacional, reivindicaram a legitimação do Conselho de Gestão Compartilhada e Participativa do Programa Pontos de Memória e a institucionalização do programa frente às propostas sugeridas pela Coordenação de Museologia Social e Educação (Comuse) ${ }^{14}$ do Ibram.

14 A Comuse é o departamento do Ibram responsável pelo Programa Pontos de Memória. 
Na Figura 3, a seguir, o registro dos representantes das iniciativas comunitárias de Pontos de Memória, colaboradores e funcionários do Ibram reunidos no $7^{\circ}$ Fórum Nacional de Museus. Na imagem os participantes estão debatendo sobre os principais encaminhamentos surgidos ao longo do evento: 1) a transformação do Conselho de Gestão Compartilhada e Participativa do Programa Pontos de Memória em Comitê Consultivo (proposta da procuradora do Ibram na IV Teia da Memória); 2) a representatividade desse comitê em apenas cinco representantes da sociedade civil; 3) a promoção da V Teia da Memória.

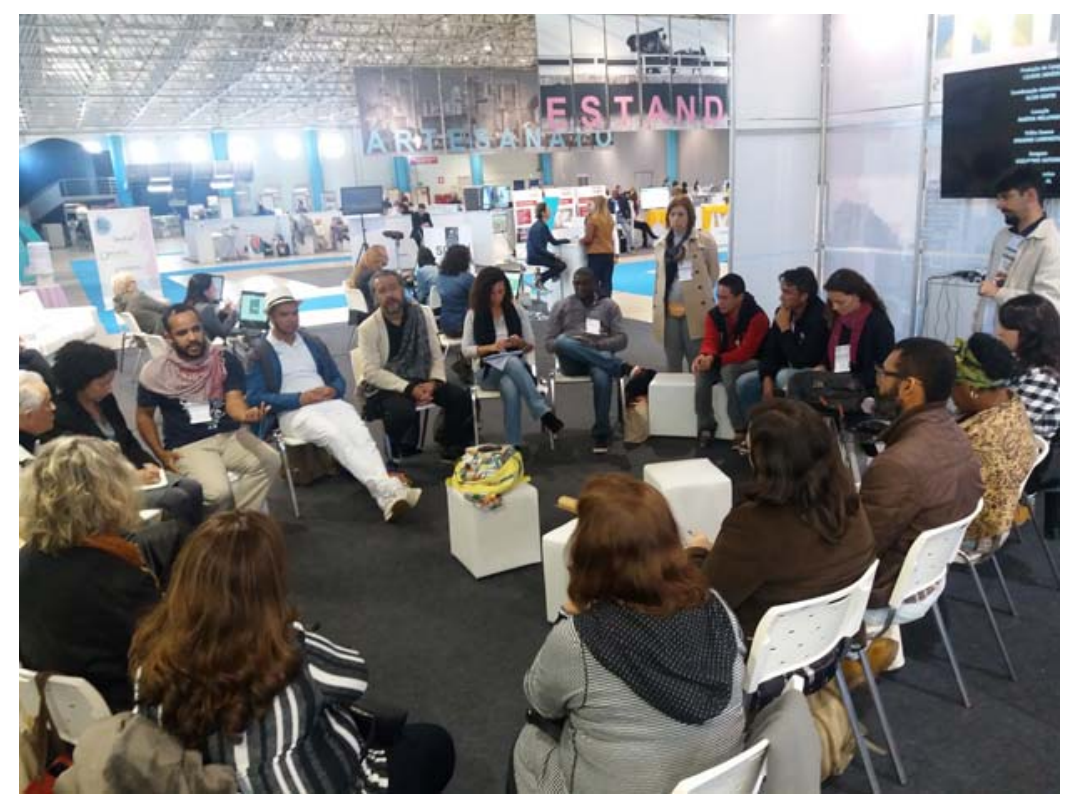

Figura 3. Reunião dos representantes dos Pontos de Memória e funcionários do Ibram durante o $7^{\circ}$ Fórum Nacional de Museus (foto da autora, 2017).

Estive no $7^{\circ}$ Fórum Nacional de Museus realizando minha primeira etapa de campo para a tese de doutorado, e observei no evento que havia uma pretensão da atual gestão do Ibram de desarticular a representação das iniciativas comunitárias na gestão participativa do Programa Pontos de Memória. Contudo, as iniciativas necessitaram se rearticular para negociar a permanência da 
participação popular na implementação das políticas voltadas para a memória e museologia comunitária. Nos bastidores do evento, os representantes das iniciativas debateram que a formação do Comitê Consultivo poderia agilizar o processo de institucionalização do PPM, no entanto, não aceitaram a formação por cinco integrantes, haja vista que dez representantes foram eleitos frente às demais iniciativas de Pontos de Memória.

De todo modo, após a reunião registrada na Figura 3, ficou acordado que o Conselho de Gestão Compartilhada e Participativa do Programa Pontos de Memória transformar-se-ia no Comitê Consultivo do Programa Pontos de Memória (CCPPM), com participação na primeira gestão dos dez representantes eleitos na IV Teia da Memória, em 2014; além disso, seriam viabilizados pelo Ibram os encontros por canal virtual e, anualmente, um encontro presencial. Todos se comprometeram em tornar possível a V Teia da Memória, buscando parcerias com instituições públicas locais e organizações civis de interesse comum.

Os desdobramentos desse encontro resultaram na institucionalização do Programa Pontos de Memória, pela portaria $n^{\circ} 315$, de 6 de setembro de 2017 (Instituto Brasileiro de Museus, 2017a), com garantia de participação da sociedade civil em sua condução com publicação do regimento interno ${ }^{15}$ do Comitê Consultivo.

A museologia comunitária associada ao PPM é um movimento teórico e político que tem força no campo dos museus brasileiros, que se fundamenta na utilização da memória social "como meio de elaboração de narrativas contra-hegemônicas, repercutindo em museus comunitários, populares, sociais e ecomuseus", conforme afirmam Gouveia e Pereira (2016, p. 731). Por sua vez, a memória social é tida como um processo que compõe as relações e afetos ao propiciar representações sociais, presente entre o movimento do que lembrar e do que esquecer, e pode ser um instrumento político de intervenção na vida social (Abreu, 2016; Gondar, 2009, 2016; Lifschitz, 2016). Os Pontos de Memória pioneiros são tomados por esse movimento teórico que reformula práticas e saberes comunitários em torno de suas memórias.

Na institucionalização do PPM, essas iniciativas são reconhecidas como tais - pontos pioneiros. A legitimidade desses grupos perante o Estado muito se deve à sua organização política, que pressiona o Ibram para que o Programa

15 O regimento interno foi aprovado durante a primeira reunião presencial do Comitê Consultivo, realizada em junho de 2017, na cidade de Brasília. 
Pontos de Memória não perca a participação popular nas tomadas de decisão e que garanta a relação estreita com essas iniciativas comunitárias. Portanto, quando proponho desenhar o campo etnográfico dessa pesquisa - museus e periferias - a organização política dos pontos pioneiros é o elo que interliga essa tomada de decisão no trabalho científico.

Os processos museológicos pesquisados não são processos fechados em si mesmos (Sahlins, 1997). Quando se apreendem formas de sociabilidade e comunicação das iniciativas de Pontos de Memória, verifica-se que elas se estendem para além dos bairros em que acontecem. As tomadas de negociação em redes organizadas atingem dimensões nacionais, como foi possível acompanhar nesta seção a mobilização para garantir a participação popular na política pública, que diretamente mexe com as estruturas operantes que colocam esses grupos em situações de invisibilidade.

De todo modo, apreende-se como as tomadas de negociação entre Ibram e os Pontos de Memória representam uma estratégia política para ambas as partes. O Estado por meio do Instituto legitima o PPM como uma politica pública de sucesso, ao garantir a participação popular desde as primeiras ações do programa. Por sua vez, os Pontos de Memória tentam manter-se atuantes frente às decisões tomadas pelo Estado, na busca pela garantia de continuação e legitimidade dos processos museológicos e no fortalecimento das redes das iniciativas para o cumprimento de ações e articulação entre sociedade civil e o poder público.

As reflexões sobre os pontos pioneiros contribuem para repensar os museus nos últimos anos no país, por agregar a categoria Pontos de Memória no campo museológico, incorporando amplas dimensões simbólicas e sociais. No entanto, o processo museológico acontece de mesmo modo nas diferentes apreensões culturais, pois dentro de um determinado território há transformação de um conjunto patrimonial em acervo museológico que define esse espaço musealizado (o museu) cabível de memória e representação, conforme a necessidade da comunidade detentora desses patrimônios (Moura, 2016).

Esses grupos se organizam politicamente por meio da memória se utilizando de metodologias e práticas museológicas com a intenção de provocar transformações sociais em seus territórios. Dessa maneira, se utilizam do Programa Pontos de Memória para garantir que essas transformações sejam direitos exercidos e conquistados. Por isso, se organizam coletivamente para que o PPM seja de fato uma política pública cultural. 


\section{O museu na periferia}

A Terra Firme constitui-se como bairro desde 1970 a partir da articulação e organização dos moradores (oriundos em sua maioria do interior do estado do Pará) por meio de centros comunitários e associações que ocuparam terras pertencentes à Universidade Federal do Pará. Os principais elementos que delimitam o bairro, geograficamente, são o rio Tucunduba e a Avenida Perimetral, que foram importantes no processo de ocupação, pois foi a partir dessas extremidades que os moradores passaram a redesenhar a área visando os investimentos que estavam destinados a esse lugar com a recém-chegada universidade. Com adjacência aos bairros do Marco, Canudos, Guamá, Universitário e Curió-Utinga, atualmente é considerado como um dos bairros mais populosos da cidade de Belém, com aproximadamente 62.000 habitantes.

O nome do lugar é ironia à área alagada que sofria constantemente influência das chuvas e marés, vindas do rio Tucunduba e afluentes do rio Guamá, que deságuam na área central de Belém. Sem condições de moradia digna, os primeiros moradores encontraram apenas uma estreita faixa considerada terra firme, por isso o nome. Na Figura 4, é possível identificar a influência das águas no bairro da Terra Firme com o registro do rio Tucunduba.

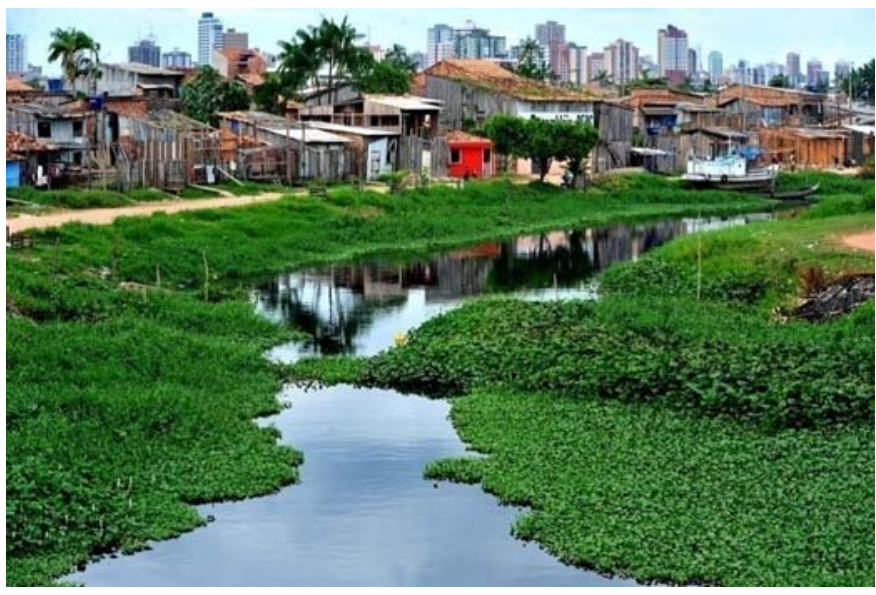

Figura 4. Rio Tucunduba, que deságua no bairro da Terra Firme, em Belém (foto: Mário Quadros, 2013 - acervo do Ponto de Memória da Terra Firme). 
O bairro da Terra Firme na cidade de Belém tem atribuição de lugar perigoso, controlado pelo tráfico de drogas, dominado pela violência e, logo, marginal. Atribuem-se, assim, estereótipos negativos ao território que influenciam diretamente na baixa autoestima da grande maioria de seus moradores. No entanto, é importante enfatizar que a violência é recorrente em toda cidade, porém o processo histórico de ocupação que resultou no abandono do poder público no bairro e os índices de violência elevados constantemente faz com que o bairro da Terra Firme sofra preconceitos até hoje.

Em contrapartida, diversos grupos culturais surgem no bairro em combate às situações de descaso e imposição do poder público e a outros segmentos da sociedade belenense. Os grupos contribuem para melhoria da qualidade de vida ao propiciarem aos moradores espaços de sociabilidades e discussões dos problemas recorrentes em Terra Firme. Assim, encontram-se no lugar projetos culturais voltados para a dança, teatro, música, expressão corporal; organizações de moradores preocupadas com a falta de espaços de lazer e áreas arborizadas no território; associações de pais e mães que participam de conselhos nas escolas públicas do lugar; dentre tantos outros tipos de iniciativas comunitárias importantes para o bem-estar do território como um todo.

O Ponto de Memória da Terra Firme consolida-se no bairro com o mesmo comprometimento das outras iniciativas comunitárias de contribuir para a melhoria da qualidade de vida dos moradores por meio de ações que viabilizem transformações sociais no lugar. As ações realizadas pelo PMTF se constituem no processo museológico do território, de valorização da memória social e do patrimônio cultural produzidos no bairro da Terra Firme. Desde 2009, vem se transformando em um museu comunitário na periferia de Belém, de formação da consciência das comunidades que o museu serve, contribuindo para levá-las a agir em reação às desigualdades e tensões sociais, permitindo maior proximidade da instituição ou iniciativa com o público, atribuições do que se é entendido como museu integral (Scheiner, 2012).

Quando o Ponto de Memória da Terra Firme iniciou suas atividades eu era bolsista de iniciação científica do Museu Paraense Emílio Goeldi (MPEG), ${ }^{16}$ desenvolvendo pesquisa no município de Curuçá (a 130 km de Belém) sobre a

16 O Museu Paraense Emílio Goeldi é uma instituição de pesquisa, centenária, vinculada ao Ministério da Ciência, Tecnologia, Inovação e Comunicação do Brasil, e está localizado na cidade de Belém. 
formação de um ecomuseu com povos tradicionais da Resex Mãe Grande de Curuçá. Atuava no bairro da Terra Firme dentro do projeto de extensão "O Museu Goeldi leva educação e ciência à comunidade", coordenado por minha orientadora, na época, Helena Quadros, ${ }^{17}$ que desde 1985 realiza um trabalho comunitário com os bairros de periferia, localizados no entorno de seu campus de pesquisa.

Os moradores do bairro da Terra Firme são os mais atuantes dentro do projeto de extensão, com participação de alguns moradores desde a sua fase inicial, como João Batista; Maria Francisca, conhecida como Chicona; Francisca Rosa, a Chiquinha; Eliete Santana, a Nerci. Esses comunitários estiveram presentes nas lutas pela formação do bairro e pelo anseio na melhoria da qualidade de vida em Terra Firme.

Em outros momentos, pude analisar mais de perto essa relação entre o Museu Goeldi e os moradores do bairro da Terra Firme (Moura, 2016). Mas se faz necessário mencionar que o MPEG contribuiu para a formação crítica desses moradores, ao revelar o museu como um espaço de educação não formal que permite ao morador fazer suas próprias escolhas com suas preferências ao participar e interagir com o acervo do museu. Criou-se uma relação de pertencimento dos moradores com o museu, que eles têm como um espaço de livre circulação, de debates e afirmações.

A relação próxima entre a comunidade do bairro da Terra Firme e o Museu Goeldi despertou, antes mesmo da chegada do Ibram, o interesse desses moradores em possuir seu próprio museu. Ao identificar essa vontade de registro, compartilhamento e preservação das memórias do bairro da Terra Firme, o instituto integrou a comunidade do bairro à ação-piloto do Programa Pontos de Memória. Partiu daqueles moradores envolvidos no projeto de extensão do MPEG a mobilização para a formação do Ponto de Memória da Terra Firme.

Contribuí com a equipe formada por Batista, Chicona, Chiquinha, Nerci e Helena na mobilização dentro do bairro da Terra Firme pra a formação do Conselho Gestor do Ponto de Memória da Terra Firme, fazendo chamadas públicas no bairro com indivíduos ou entidades que poderiam agregar na condução do projeto. Integrei-me à primeira formação do Conselho Gestor do $\mathrm{PMTF}_{1}^{18}$ formada

17 Coordenadora de projetos em educação museal e museologia comunitária no Serviço de Educação do Museu Paraense Emílio Goeldi.

18 A primeira formação do Conselho Gestor do Ponto de Memória da Terra Firme foi eleita em maio de 2010 durante o Seminário de Criação do Conselho Gestor do Ponto de Memória da Terra Firme, com 16 membros. 
por moradores do bairro e pessoas que assim como Helena e eu eram atuantes dentro de projetos e outros tipos de iniciativas comunitárias; juntos desenvolvemos diversas atividades relacionadas às áreas de educação e museologia. Isso propiciou: a consolidação do conselho gestor, havendo o reconhecimento do grupo como uma entidade cultural no bairro; o desenvolvimento de práticas de educação popular e museologia social com os moradores e seus pares; e a aplicação de rodas de conversa e inventários participativos, recorrentemente.

No curso do processo museológico seguimos com o interesse de contribuir na mudança da imagem negativa do bairro e na autoestima de seus moradores, desenvolvendo ações principalmente com a juventude dali, grupo social que mais sofre com as atribuições negativas do lugar. Na Figura 5 há uma matéria jornalística sobre a I Gincana História e Memória do bairro da Terra Firme (2010), que envolveu jovens de projetos culturais e estudantes de escolas públicas do bairro. A reportagem que circulou pela Grande Belém abriu possibilidades de reconhecimento do bairro da Terra Firme como um lugar de representação sociocultural importante para a cidade.

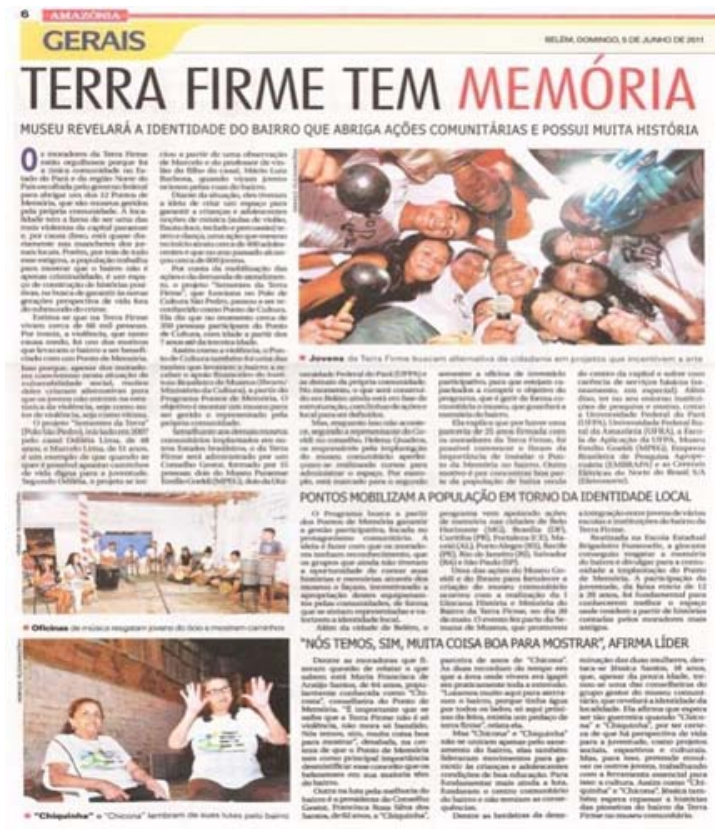

Figura 5. O bairro da Terra Firme em veículo de comunicação a partir de uma ação do Ponto de Memória da Terra Firme (Terra..., 2011). 
No ano de 2011, tornou-se pública a contratação de consultorias técnico-operacionais para atuarem nas comunidades integrantes da ação-piloto do Programa Pontos de Memória, a fim de viabilizar a realização de inventários participativos locais e a elaboração de produtos de difusão de promoção das iniciativas comunitárias. Na Terra Firme, essa função coube a mim. E assim, no primeiro momento, como consultora, tratei junto aos demais conselheiros do PMTF a elaboração do nosso plano de ação, a ser executado até janeiro de 2013.

Realizamos o inventário participativo, entre os anos de 2011 e 2012, com o objetivo de pesquisar, catalogar e sistematizar as linguagens culturais, a história e a memória presentes no bairro da Terra Firme, por meio de entrevistas com os moradores, a fim de dar suporte e visibilidade aos diversos grupos socioculturais do bairro, contribuindo para a valorização dos saberes e práticas locais (Moura, 2016). Dez jovens moradores do bairro foram responsáveis por realizar as entrevistas sob orientação de uma comissão de trabalho formada entre os conselheiros do PMTF. O inventário participativo nos possibilitou levantar um acervo de histórias de vida de atores sociais importantes para a formação da memória social do bairro da Terra Firme.

Foram coletadas 59 histórias de vida, que registraram aspectos da cultura, do cotidiano, da história e do processo de luta e conquistas dos moradores do bairro. Nos relatos identificamos o interesse dos moradores em registrar, preservar e divulgar elementos que tratam do patrimônio reconhecido, da memória compartilhada e da identidade afirmada dentro do bairro da Terra Firme. Apesar de muitos ponderarem a violência do lugar como ameaça ao patrimônio público, consideraram que o trabalho feito pelo Ponto de Memória era importante para mudar os estereótipos negativos atribuídos ao lugar.

A partir do que foi inventariado montamos grupos de trabalho para dar continuidade ao plano de ação, cada grupo era responsável pela produção de uma atividade específica que gerou produtos de difusão a partir de oficinas de formação com moradores do bairro. As ações aconteceram ao longo do ano de 2012 em diversos espaços do bairro e nas instalações do Museu Goeldi. Produzimos, dentre oficinas, seminários, cursos voltados para museologia comunitária e educação popular: 1) Cortejo Cultural pelas principais ruas da Terra Firme; 2) produção de dois vídeos documentários que retratam a importância das feiras livres para o morador (do feirante ao consumidor) e o registro de grupos culturais do bairro; 3) (re)edição do jornal comunitário $O$ Tucunduba; 
4) a concepção coletiva da exposição itinerante denominada Terra Firme de Tudo um Pouco (ver Figura 6).

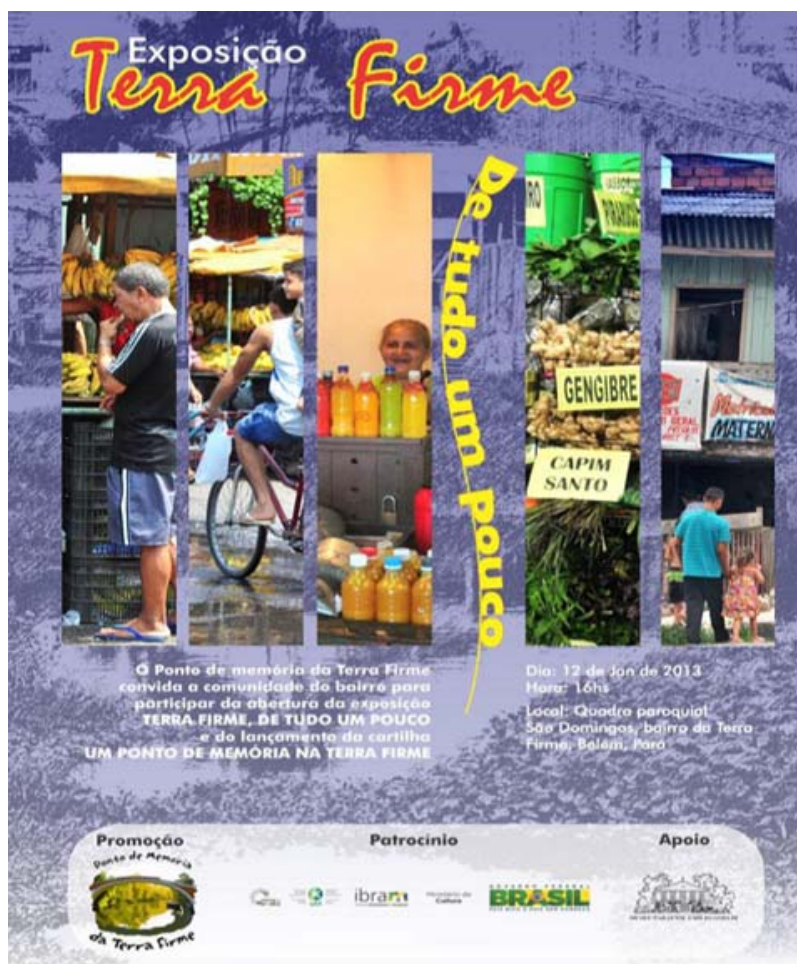

Figura 6. Cartaz de divulgação da exposição Terra Firme de Tudo um Pouco (projeto gráfico: Carlota Brito, 2013).

Naquele momento, se bem me recordo, desejávamos implantar, de fato, um museu comunitário no bairro (Quadros; Moura; Quadros, 2013) que pudesse contribuir na mudança da imagem negativa atribuída ao lugar, apropriando-se das memórias narradas pelos seus moradores. Esse desejo não era apenas do Ponto de Memória da Terra Firme; como consultora, naquele momento, conheci várias iniciativas pelo país que nos encontros nacionais manifestavam a mesma vontade. $\mathrm{O}$ fato é que havia uma pretensão dentro 
do PPM, pelo menos inicialmente, de que as iniciativas comunitárias definissem ao longo de seus processos de implantação local o tipo de representação museal (de território, comunitário, ecomuseu, interativo) que gostariam de ter em sua comunidade, elegendo memórias e histórias para serem salvaguardadas em museus. Contudo, no decorrer do tempo elas foram incorporando amplas dimensões simbólicas ao que estavam produzindo, refletindo sobre os temas, significados e objetos adquiridos em suas ações, distanciando-se, assim, do que haviam projetado a elas.

Essa reflexão é possível quando identifico, nos últimos anos como antropóloga em formação, que houve uma (res)significação da categoria museu nesses processos museológicos incentivados pelo Programa Pontos de Memória, posto que a maioria das 12 comunidades integradas à ação-piloto do programa não ditam, não nomeiam ou se não conceituam como museus, definindo-se como Pontos de Memória, categoria criada pelo Estado. De todo modo, o que antes era colocado para identificar dinâmicas de memória que levariam à concepção de museus (como são conhecidos) é apropriado pelas comunidades através da categoria Pontos de Memória para dar a ela novo sentindo e nova dinâmica de trabalho.

O embate entre ser ou não ser museu foi o que me levou a cursar antropologia, em 2014, visualizando na ciência a possibilidade de compreensão do que estava acontecendo, especialmente no bairro da Terra Firme. No exercício do fazer antropológico aliado à minha experiência como parte integrante do processo museológico no bairro observo que, apesar de os Pontos de Memória não se nomearem como museus, os sujeitos envolvidos no processo pensam e agem como museu. Estes são cabíveis de representação em museus comunitários por desenvolverem trabalhos com o patrimônio cultural do território, visando participação dos moradores no desenvolvimento cultural e socioeconômico das comunidades as quais representam.

Tornei-me colaboradora no Ponto de Memória da Terra Firme nos últimos quatro anos; desenvolvo pesquisas com processos museológicos comunitários próximos da realidade do bairro da Terra Firme, investigando como os sujeitos envolvidos apreendem e percebem os museus. Assim, constantemente faço trabalho de imersão na Terra Firme para compreender como grupos como o PMTF se organizam conforme as novas dinâmicas de ser e estar nas cidades. Esse trabalho me permite acompanhar diversas ações que recorrentemente acontecem 
ao longo do ano, e torno-me uma "força trabalho" quando há necessidade de desenvolver atividades e de mobilização entre o conselho gestor.

No exercício dessa função tenho realizado atividades com outras colaboradoras no Ponto de Memória da Terra Firme, especialmente com Camila Quadros. ${ }^{19}$ Juntas, realizamos em 2017 a oficina "Viver para lembrar, morrer para esquecer? A Terra Firme e sua representação museal" no bairro da Terra Firme, durante a programação da $15^{\mathrm{a}}$ Semana Nacional de Museus, com apoio e participação dos conselheiros do PMTF. A ação teve como objetivo identificar como o processo museológico acontece no bairro, levando em consideração os relatos e conflitos íntimos dos seus moradores. Identificamos ao longo da programação que há uma vontade de autorrepresentação dos moradores de Terra Firme em espaços, como os museus, partindo do ato de lembrar, reviver e reconstruir novos mundos no território que vivem (Bosi, 1994).

Os processos museológicos que têm acontecido nas periferias brasileiras, como em Terra Firme, são resultados da nova forma de experimentar as interações sociais dentro da cidade, onde indivíduos e grupos buscam maneiras de compartilhar o que seria o urbano - o sentimento de ser e o que pretende ser dentro de uma rede de informação e contatos com pessoas e instituições sociais (García Canclini, 2008). Não há como definir o que seriam cidades, nem é a intenção dessa pesquisa. No entanto, deseja-se refletir sobre de que forma os museus contribuem para que grupos compartilhem o urbano em suas cidades.

\section{Considerações finais}

O museu passou a atuar junto a determinados grupos sociais, inspirando a formação de outros tipos de representação do fenômeno, como os museus comunitários. Frente a essas transformações, grupos sociais excluídos de qualquer coisa que coloque em ordem o urbano passaram a desempenhar processos museológicos acreditando no poder dos museus de propiciar mudanças sociais, culturais e políticas de suas realidades. Assim, organizam-se politicamente em torno de suas memórias e de seus patrimônios a fim de provocar e estimular

19 Pedagoga, especialista em Educação, Pobreza e Desigualdade Social (GEAM/UFPA); mestra em Educação (PPGED/UFPA). 
mudanças nas estruturas opressoras sob as quais são colocados dentro de suas cidades. Nessa pesquisa são chamados de Pontos de Memória.

Os Pontos de Memória são iniciativas comunitárias que desenvolvem processos museológicos em seus territórios de pertença, comtemplados pelo Programa Pontos de Memória - política pública de memória social e museologia comunitária do Instituto Brasileiro de Museus. No bairro da Terra Firme, em Belém, o processo museológico é realizado pelo Ponto de Memória da Terra Firme, por meio de ações que refletem sobre as realidades de um bairro marginalizado dentro da capital paraense.

Poder falar em primeira pessoa e militar a favor de suas necessidades tem contribuído para a valorização da memória social dos sujeitos envolvidos nos Pontos de Memória, bem como o fortalecimento de suas identidades, impulsionando a melhoria da qualidade de vida de comunidades periféricas, sobretudo no que se refere à autoestima dos moradores de periferia que enfrentam violência física e moral diariamente devido ao abandono e descaso público.

A forma com que os sujeitos envolvidos nos processos museológicos apreendem a cidade deve-se às redes de sociabilidades que criam para atender as necessidades pessoais e territoriais. A vontade política que permeia essas redes busca intervir nas realidades jurídica, cultural e política por meio de narrativas e dinâmicas de memória. Desse modo, compreende-se que os Pontos de Memória, como museus comunitários, surgem com a intenção de valorizar e enaltecer o processo de construção coletiva por meio da memória.

Por fim, faz-se necessário desbravar essas iniciativas tomando como ponto de partida os desdobramentos dessa política pública, ao levar em consideração o modo como os sujeitos envolvidos nos processos apreendem os museus, tema para um próximo texto. Contudo, espero, mesmo de maneira breve, ter contribuído, com a experiência dos Pontos de Memória, nos debates de museus e cidades. 


\section{Referências}

ABREU, R. Tal antropologia, qual museu?. In: ABREU, R.; CHAGAS, M. de S.; SANTOS, M. S. dos (org.). Museus, coleções e patrimônios: narrativas polifônicas. Rio de Janeiro: Garamond: MinC/Iphan/Demu, 2007. p. 138-178. (Coleção Museu, Memória e Cidadania).

ABREU, R. A emergência do "Outro" no campo do patrimônio cultural. Revista do Museu de Arqueologia e Etnologia, São Paulo, supl. 7, p. 9-20, 2008.

ABREU, R. A metrópole contemporânea e a proliferação dos "museus espetáculos". Anais do Museu Histórico Nacional, Rio de Janeiro, v. 44, p. 53-71, 2012.

ABREU, R. Memória social: itinerários poéticos-conceituais. Revista Morpheus, Rio de Janeiro, v. 9, n. 15, p. 41-66, 2016. Número especial: Por que memória social?.

ABREU, R.; LIMA FILHO, M. F. A trajetória do GT de Patrimônios e Museus da Associação Brasileira de Antropologia. In: TAMASO, I. M.; LIMA FILHO, M. F. (org.). Antropologia e patrimônio cultural: trajetórias e conceitos. Brasília: Associação Brasileira de Antropologia, 2007. p. 21-44.

AVELAR, L. Museus comunitários no Brasil: o Ponto de Memória Museus do Taquaril. 2015. Dissertação (Mestrado em Bens Culturais e Projetos Sociais) - Centro de Pesquisa e Documentação de História Contemporânea do Brasil, Fundação Getúlio Vargas, Rio de Janeiro, 2015.

BOSI, E. Memória e sociedade: lembrança dos velhos. 3. ed. São Paulo: Companhia das Letras, 1994.

CHAGAS, M.; ABREU, R. Museu da Maré: memórias e narrativas a favor da dignidade social. Musas, n. 3, p. 130-152, 2007.

CHAGAS, M.; GOUVEIA, I. Museologia social: reflexões e práticas (à guisa de apresentação. Cadernos do CEOM, ano 27, n. 41, p. 9-22, 2014.

GARCÍA CANCLINI, N. Cultura transnacional y culturas populares. Lima: Roncagliolo, 1988.

GARCÍA CANCLINI, N. Imaginários culturais da cidade: conhecimento/espetáculo /desconhecimento. In: TEXEIRA COELHO, J. (org.). A cultura pela cidade. São Paulo: Iluminuras: Itaú Cultural, 2008. p. 15-31.

GLUCKMAN, M. Análise de uma situação social na Zululândia moderna. In: FELDMAN-BIANCO, B. (org.). Antropologia das sociedades contemporâneas: métodos. São Paulo: Global, 2010. p. 227-344.

GONÇALVES, J. R. Ressonâncias, materialidade e subjetividade: as culturas como patrimônios. Horizontes Antropológicos, Porto Alegre, ano 11, n. 23, p. 15-36, jan./jun. 2005. 
GONDAR, J. Quatro proposições sobre memória social. In: GONDAR, J.; DODEBEI, V. (org.). O que é memória social?. Rio de Janeiro: Contra Capa, 2009. p. 11-27.

GONDAR, J. Cinco proposições sobre memória social. Revista Morpheus, Rio de Janeiro, v. 9, n. 15, p. 19-40, 2016. Número especial: Por que memória social?.

GOUVEIA, I.; PEREIRA, M. A emergência da museologia social. Políticas Culturais em Revista, v. 9, n. 2, p. 726-745, 2016.

HANNERZ, U. Explorando a cidade: em busca de uma antropologia urbana. Petrópolis: Vozes, 2015.

INSTITUTO BRASILEIRO DE MUSEUS. Carta dos Pontos de Memória e inciativas comunitárias em memória e museologia social. Brasília, 2012.

INSTITUTO BRASILEIRO DE MUSEUS. Portaria n 315, de 6 de setembro de 2017. Dispõe sobre a instituição do Programa Pontos de Memória no âmbito do Instituto Brasileiro de Museus - Ibram e dá outras providências. Diário Oficial da União, Brasília, n. 174, 11 set. 2017a. Seção 1, p. 6.

INSTITUTO BRASILEIRO DE MUSEUS. Relatório do $6^{\circ}$ Fórum Nacional de Museus: museus criativos. Brasília, 2017b.

LIFSCHITZ, J. A. Em torno da memória política. Revista Morpheus, Rio de Janeiro, v. 9, n. 15, p. 67-83, 2016. Número especial: Por que memória social?.

MAGNANI, J. Da periferia ao centro, cá e lá: seguindo trajetos, construindo circuitos. Anuário Antropológico 2012/II, p. 53-72, 2013.

MENESES, U. O museu na cidade x a cidade no museu: para uma abordagem histórica dos msueus de cidade. Revista Brasileira de História, v. 5, n. 8/9, p. 197-205, 1985.

MORAES, N. Políticas públicas, políticas culturais e museu no Brasil. Revista Museologia e Patrimônio, v. 2, n. 1, p. 54-69, 2009.

MORAES, N. Museu, poder e políticas culturais no Brasil. Musas, n. 5, p. 80-101, 2011. MORALES LERSCH, T.; CAMARENA OCAMPO, C. O conceito de museu comunitário: história vivida ou memória para transformar a história?. 2004. Disponível em: https://bibliotextos.files.wordpress.com/2011/12/o-conceito-de-museu-comunitc3alrio.pdf. Acesso em: 28 jan. 2018.

MOURA, C. A. Ponto de Memória: experiências etnográficas no museu diferente de Terra Firme, Belém-PA. 2016. Dissertação (Mestrado em Antropologia) - Instituto de Filosofia e Ciências Humanas, Universidade Federal do Pará, Belém, 2016.

ORGANIZAÇÃO DOS ESTADOS IBERO-AMERICANOS. Pontos de Memória: metodologia e práticas em museologia social. Brasília: Phábrica, 2016. 
QUADROS, C.; MOURA, C.; QUADROS, H. Um Ponto de Memória na Terra Firme. Belém: Ponto de Memória da Terra Firme, 2013.

SAHLINS, M. O "pessimismo sentimental" e a experiência etnográfica: porque a cultura não um "objeto" em via de extinção (parte II). Mana, Rio de Janeiro, v. 3, n. 2, p. 103-150, 1997.

SCHEINER, T. Repensando o museu integral: do conceito às práticas. Boletim do Museu Paraense Emílio Goeldi: Ciências Humanas, Belém, v. 7, n. 1, p. 15-30, jan./abr. 2012.

SILVA, J. Cultura periférica, a voz da periferia. 2013. Trabalho de Conclusão de Curso (Pós-Graduação em Gestão de Projetos Culturais e Organização de Eventos) - Escola de Comunicação e Artes, Universidade de São Paulo, São Paulo, 2013.

TERRA Firme tem memória. Amazônia, Belém, p. 6, 5 jun. 2011.

VAN VELSEN, J. A análise situacional e o método de estudo de caso detalhado. In: FELDMAN-BIANCO, B. (org.). Antropologia das sociedades contemporâneas: métodos. São Paulo: Global, 2010. p. 345-375.

WACQUANT, L. Urban outcasts: a comparative sociology of advanced marginality. Cambridge: Polity Press, 2007.

Recebido: 31/01/2018 Aceito: 06/11/2018 | Received: 1/31/2018 Accepted: 11/6/2018 